\title{
ASPECTOS DA PROTEÇÃO CONSTITUCIONAL E PENAL DA LIBERDADE RELIGIOSA NO ORDENAMENTO JURÍDICO BRASILEIRO
}

\author{
Márcio Eduardo Senra Nogueira Pedrosa Morais ${ }^{1}$ \\ Carlos Alberto Simões de Tomaz ${ }^{2}$
}

RESUMO: A partir de uma abordagem lógico-dedutiva, o artigo analisa a proteção da liberdade religiosa em face do consenso estabelecido na Constituição brasileira de 1988, bem como a tutela penal dessa proteção. Para tanto, estabelece uma base compreensiva da dificuldade contramajoritária que envolve os conflitos sobre a matéria, decisivamente marcada por intolerância, e aponta a tutela penal pertinente que, de regra, não é efetivada quando a atenção se volta para o âmbito da esfera cível, circunstâncias que se aponta em conclusão.

Palavras-chave: Brasil; Liberdade religiosa; Constituição brasileira de 1988; Proteção constitucional; Proteção penal.

\section{ASPECTS OF THE CONSTITUTIONAL AND PENAL PROTECTION OF RELIGIOUS FREEDOM IN THE BRAZILIAN LEGAL SYSTEM}

\begin{abstract}
From a logical-deductive approach, the article analyzes the protection of religious freedom in the face of the consensus established in the Brazilian Constitution of 1988, as well as the criminal tutelage of this protection. By this way, it establishes a comprehensive basis of the countermajoritarian difficulty that surrounds the conflicts on the matter, decisively marked by intolerance, and points out the pertinent criminal tutelage that, usually, is not effective when attention is turned to the scope of the civil sphere, circumstances which are pointed out in conclusion.
\end{abstract}

Keywords: Brazil; Religious freedom; Brazilian Constitution of 1988; Constitutional protection; Criminal protection.

\footnotetext{
${ }^{1}$ Doutor e Mestre em Teoria do Direito pela Pucminas. Professor da graduação e do Programa de Pós-graduação Stricto Sensu em Direito da Universidade de Itaúna. Professor da Faculdade de Pará de Minas-MG. Endereço: Rua Raimundo de Almeida, n. 394 - apartamento 301 - Bairro Nova Vila Mozart - ITAÚNA/MG - CEP 35680-183. Email: marcioeduardopedrosamorais@gmail.com

2 Mestre em Direito das Relações Internacionais (UNICEUB/DF). Doutor em Direito (UNISINOS/RS). Pósdoutor em Filosofia do Direito (Universidade de Coimbra/Portugal). Professor da Universidade de Vila Velha (UVV). Magistrado Federal. Endereço: Rua Bérgamo, n. ${ }^{\circ} 129$ - Bairro Bandeirantes - BELO HORIZONTE/MG - CEP 31430-370. Email: ca.tomaz@uol.com.br.
}

Revista de Direito Penal, Processo Penal e Constituição | e-ISSN: 2526-0200 | Maranhão | v. 3 | n. 2 | p. 17 - 40 | Jul/Dez. 2017. 


\section{INTRODUÇÃO}

Quando os portugueses chegaram ao Brasil, em 22 de abril de 1500, imediatamente celebraram uma missa e afixaram uma cruz. Era a mostra de que se iniciaria naquele momento uma relação que perduraria até os dias atuais. As relações entre Estado e Igreja são consideravelmente visíveis no Brasil, tendo a Igreja Católica participado ativamente de vários acontecimentos históricos importantes. Fato é que o catolicismo, durante muito tempo, foi a única religião aceita e dominante no território brasileiro, tendo os santos católicos dado nome a importantes cidades e ruas, como também oficializado feriados nacionais.

Pouco tempo depois da chegada dos portugueses, foi declarado que o povo da "Terra Brasilis” deveria ser colonizado, para isso o ensino constituiria mecanismo fundamental, tendo os jesuítas chegado à colônia no ano de 1549, sob a inspiração da Contra-Reforma, com o objetivo de evangelização, tendo sido responsáveis pela catequização indígena e pela educação da elite colonizadora.

Preocupados com a difusão da fé e com a educação da elite colonizadora, os jesuítas criaram um sistema educacional que fornecia aos elementos das classes dominantes uma educação clássica e humanista, como era o ideal europeu da época. Assim, no ano de 1550 as primeiras escolas jesuítas foram criadas, ${ }^{3}$ onde seriam ensinados a cultura portuguesa e os princípios da fé católica.

Sem a concorrência do protestantismo e com as injunções políticas e econômicas da condição colonial, a educação jesuítica reproduziu no Brasil o espírito da Idade Média, com o aprisionamento do homem ao dogma da tradição escolástica, a sua submissão à autoridade e à rígida ordenação social, avesso ao livre exame e à experimentação. Em contraste, portanto, ao homem de livre pensamento, de visão igualitária e espírito associativo, confiante no conhecimento como instrumento de transformação do mundo natural. (OLIVEIRA, 2004, p. 945).

\footnotetext{
${ }^{3}$ No século XVIII, por exemplo, a obra educativa dos jesuítas se estendia do Pará a São Paulo, com 17 colégios e seminários, 25 residências e 36 missões, sem contar os seminários menores e as escolas de alfabetização presentes em quase todo o território. (OLIVEIRA, 2004, p. 946).
}

Revista de Direito Penal, Processo Penal e Constituição | e-ISSN: 2526-0200 | Maranhão | v. 3 | n. 2 | p. 17 - 40 | Jul/Dez. 2017. 
No ano de 1759, em decorrência das reformas ${ }^{4}$ realizadas por Sebastião José de Carvalho e Mello (1699-1782), o Marquês de Pombal, ${ }^{5}$ os jesuítas são expulsos de Portugal e de suas colônias, passando outras ordens religiosas a ser responsáveis pelo ensino religioso no Brasil, extinguindo o único sistema de educação do Vice-Reinado do Brasil. Em que pese a saída dos jesuítas, a religião continuou sendo o mecanismo fundamental de evangelização da sociedade brasileira.

Apresentados esses aspectos históricos nacionais acerca da relação entre Estado (no caso, o português) e religião, é importante trazer um conceito de religião. Deste modo, de acordo com Nicola Abbagnano, por religião entende-se:

Crença na garantia sobrenatural de salvação e técnicas destinadas a obter e conservar essa garantia. A garantia religiosa é sobrenatural no sentido de situar-se além dos limites abarcados pelos poderes do homem, de agir ou poder agir onde tais poderes são impotentes e de ter um modo de ação misterioso e imperscrutável. (ABBAGNANO, 2007, p. 846).

A Suprema Corte dos Estados Unidos, no julgamento dos Mormon Cases $^{6}$ elencou três pilares para a constituição da religião: divindade, moralidade e crença. Esses três elementos constituintes estavam presentes na religião professada durante o processo colonizador português em terras brasileiras.

Em relação ao elemento moralidade, a religião católica imposta por Portugal a uma sociedade que a desconhecia é uma religião triste, do arrependimento, da punição, do pecado. Antes da colonização, esse sentimento religioso imperava na Península Ibérica, estando solidificado nas suas práticas sociais. Essa religião do medo, da submissão, foi responsável

\footnotetext{
${ }^{4}$ A reforma pombalina insere-se no contexto histórico do despotismo esclarecido e do enciclopedismo francês, com o objetivo de recuperar o atraso da metrópole lusitana em relação a outros países europeus, pregando a abertura do ensino às ciências experimentais, tornando-o mais prático e utilitário, despertando um número cada vez maior de interessados no ensino superior. (OLIVEIRA, 2004).

5 "Ministro de Estado sob o governo de D. José I, Pombal representava, em 1759, a expressão do despotismo esclarecido; ou as feições mais específicas da combinação entre Iluminismo e razão de Estado. Sentindo-se afrontado, o ministro do Reino pretendia retirar da Companhia de Jesus o controle exercido pela Ordem sobre corações e mentes da infância e da juventude.” (BOTO, 2007).

${ }^{6}$ Os Mormon Cases referem-se a uma série de casos julgados pela Suprema Corte dos Estados Unidos em relação aos questionamentos judiciais do Estado norte-americano contra a poligamia praticada pelos mórmons, que por sua vez, alegavam a liberdade religiosa para justificarem a prática.
}

Revista de Direito Penal, Processo Penal e Constituição | e-ISSN: 2526-0200 | Maranhão | v. 3 | n. 2 | p. 17 - 40 | Jul/Dez. 2017. 
por aprisionar indivíduos em seus pensamentos, impedindo a manifestação daqueles que ousassem discordar daquilo que era imposto como moral pela fé cristã.

O marco dessa fé cristã era a cruz, presente nos cemitérios, nas igrejas, escapulários, ruas, praças, caravelas. As imagens de santos existiam por toda parte, e a missa e a procissão eram acontecimentos sociais, manifestações coletivas que iriam se repetir no Novo Mundo. (RIOS, 1994). A cruz dominou e conquistou a América, seja substituindo Quetzalcoatl a Guadalupe no México, seja misturando religiões africanas, catolicismo e crenças indígenas no Brasil. ${ }^{7}$ Por intermédio da justificativa do catolicismo, várias etnias foram dizimadas, populações foram escravizadas, ou seja, a religião foi utilizada de maneira destrutiva, amparando-se no seu poder simbólico.

Posteriormente, a religião foi se institucionalizando na estrutura colonialista e, durante o período de emancipação, no poder do Estado brasileiro. Essa relação religião-estado sempre foi vista como normal, não tendo o Estado brasileiro, em nenhum momento de sua história, perseguido ou tentado enfraquecer a Igreja, de maneira concreta. Do contrário, sempre manteve bons diálogos, sendo a Santa Madre importante intercessora de assuntos políticos, marcando fortemente momentos fundamentais da história nacional.

Apesar de laico, é visível o papel desempenhado pelas instituições religiosas nos debates e decisões nacionais. Contrariamente ao que acontece na França, o Brasil não persegue suas instituições religiosas. É uma laicidade que se assemelha ao modelo norteamericano, tentando impor um muro de separação entre Estado e Igreja no que se refere às relações estatais. Em muitos lugares é comum o padre se assentar ao lado de prefeitos, vereadores, governadores, deputados, durante cerimônias públicas, consistindo uma autoridade, principalmente nos pequenos municípios.

Enquanto a religião católica era defendida e oficializada no período monárquico, outras religiões estavam alijadas da sociedade, como ocorreu com o candomblé e outras

\footnotetext{
${ }^{7}$ Em relação à pluralidade religiosa no Brasil saliento que, em 1950, de uma população total de 51.806.591 de habitantes, a percentagem de católicos era de $93,7 \%$ e de protestantes 3,4\%; em 1991, de uma população de 146.815.818 habitantes, 82,96\% eram católicos e 9,34\% eram protestantes; em 2000, de uma população de 169.799.170 habitantes, 73,60\% eram católicos e 15,41\% protestantes. (MENDONÇA, 2003). No ano de 2010, o Instituto Brasileiro de Geografia e Estatística - IBGE contabilizou 64,6\% de católicos no Brasil e 22,2\% de protestantes no Brasil.
}

Revista de Direito Penal, Processo Penal e Constituição | e-ISSN: 2526-0200 | Maranhão | v. 3 | n. 2 | p. 17 - 40 | Jul/Dez. 2017. 
religiões de matriz africana. Esse contexto de imposição da fé católica, como também de exclusão de determinadas religiões do contexto social, demanda a atuação da tutela penal.

Assim, esposadas essas considerações iniciais acerca da religião na vida social e cultura do país, passa-se à temática que permeia a presente pesquisa, qual seja: a proteção penal da liberdade religiosa no direito brasileiro.

Considerando a liberdade religiosa e suas vertentes um direito fundamental, é necessária a sua proteção efetiva por parte do Estado, principalmente por intermédio do direito penal.

O problema metodológico, ou seja, a pergunta que permeia a pesquisa é: qual é a proteção jurídico-penal da liberdade religiosa no ordenamento jurídico brasileiro? Tendo como base o princípio da proporcionalidade, seria essa proteção eficiente?

O princípio da proporcionalidade possui duas vertentes, a primeira a proibição do excesso, a segunda a proibição da proteção deficiente. Nesse sentido, fere o princípio da proporcionalidade não somente penas excessivas, mas também as penas aquém do quantum necessário para a proteção do bem jurídico-penal, como também a atuação deficiente do sistema punitivo nos casos concretos.

Deste modo, parte-se da hipótese de que há uma proteção penal deficiente em relação ao princípio da liberdade religiosa, principalmente em relação à aplicação concreta do direito penal por parte do Estado, no que se refere à questão estudada, o que fere a estrutura do Estado Democrático de Direito.

A pesquisa é importante (deste modo se justifica) por se relacionar com um aspecto humano fundamental, sua liberdade de religião (de crer, como também de não crer), principalmente nos dias atuais, com várias passagens de intolerância e desrespeito às diferenças, principalmente religiosas, provocando conflitos, desuniões e até mesmo guerras, sem falar em ataques terroristas, que, possuem importante viés religioso.

Estruturalmente, além de introdução e conclusão, o presente trabalho é constituído por três outras seções em sua parte textual. Na seção 2, intitulada Considerações sobre o princípio da liberdade religiosa, serão estudadas, ainda que brevemente, passagens históricas sobre a liberdade religiosa. A seção 3 (A compreensão da liberdade religiosa no contexto da Constituição da República Federativa do Brasil de 1988) objetiva a compreensão do

Revista de Direito Penal, Processo Penal e Constituição | e-ISSN: 2526-0200 | Maranhão | v. 3 | n. 2 | p. 17 - 40 | Jul/Dez. 2017. 
princípio em face do arranjo democrático estabelecido pela Constituição de 1988. Por sua vez, na seção 4, com o título A proteção penal da liberdade religiosa no ordenamento jurídico brasileiro, serão analisados os dispositivos penais do ordenamento jurídico brasileiro que objetivam a proteção penal da liberdade religiosa.

Para a realização da pesquisa foram utilizadas as normas constitucionais e infraconstitucionais sobre a matéria, além de doutrinas nacionais e estrangeiras, como também matérias jornalísticas e relatório estatístico, constituindo os dados de realidade, enfrentados a partir de um exame analítico-crítico.

\section{CONSIDERAÇÕES SOBRE O PRINCÍPIO DA LIBERDADE RELIGIOSA}

A liberdade religiosa é um princípio que se desenvolve tardiamente na história, compondo, juntamente com o princípio democrático e o princípio da igualdade, o princípio da laicidade. Trata-se de gênero do qual derivam diversas categorias, dentre outras: a liberdade de professar a própria crença; o direito à privacidade religiosa; a liberdade de informar e se informar sobre religião; o direito à assistência religiosa em situações especiais; o direito de produção de obras científicas sobre religião; o direito à objeção de consciência por motivo de crença religiosa; a liberdade de exercício das funções religiosas e do culto. (MORAIS, 2015).

Historicamente, a liberdade de crença e de culto era tolerada nos Estados antigos, desde que não contrariasse a ordem estatal, como também não afetasse a segurança do Estado. No ano de 313, Constantino e Licínio, por intermédio do edito de 13 de junho de 313, aboliram a antiga religião oficial, decretando a liberdade de consciência.

Pouco tempo depois, em 379, essa liberdade foi abolida, tendo os imperadores Graciano e Valentiniano II, no Império do Ocidente, e Teodósio I, no Império do Oriente, proclamado o cristianismo como a religião oficial do Império. A partir desse momento tem-se início as punições por blasfêmia (injúria religiosa), consistindo, essas injúrias, em simples ofensas irrogadas contra o catolicismo. "Sobreveio a intolerância religiosa, que atingiu seu auge na Idade Média, mantida a religião católica como religião do Estado. O bracchium saeculare foi tremendo e inexorável ao serviço da Igreja cristã.” (HUNGRIA; LACERDA; FRAGOSO, 1981, p. 50).

Revista de Direito Penal, Processo Penal e Constituição | e-ISSN: 2526-0200 | Maranhão | v. 3 | n. 2 | p. 17 - 40 | Jul/Dez. 2017. 
Em nível nacional, o princípio da liberdade religiosa somente foi institucionalizado em 1890, por intermédio do Decreto n. ${ }^{\circ}$ 119-A, de 7 de janeiro de 1890. (BRASIL, 2017c). Até então, o Brasil teve a religião católica apostólica romana como sua religião oficial, condição que perdurou desde a Constituição monárquica de 1824, a qual trazia em seu artigo $5^{\circ}$ que “[...] A Religião Católica Apostólica Romana continuará a ser a Religião do Império. Todas as outras Religiões serão permitidas com seu culto doméstico, ou particular em casas para isso destinadas, sem forma alguma exterior do Templo.” (BRASIL, 2017a). Deste modo, o referido decreto promoveu a separação entre Estado e Igreja, desaparecendo a figura do Padroado - o beneplácito que consistia na doação de recursos pelo Poder Público à realização do culto religioso.

Todas as Constituições seguintes previram a garantia formal da liberdade religiosa em seus textos, em que pese algumas liberdades relacionadas ao princípio não coadunarem com o seu conteúdo, como é o caso do ensino religioso, que foi oficializado em discordância aos postulados da referida liberdade. ${ }^{8}$

Consistindo num dos mais importantes bens jurídicos do ser humano, a liberdade religiosa deve ser protegida pelo ordenamento penal, consubstanciando sua ofensa um ato de desestabilização da paz social, que potencialmente corrompe a regular convivência em sociedade. Deste modo, sua proteção não ofende o princípio da intervenção mínima.

Contrariamente, a preservação da liberdade religiosa coaduna com o respeito a um direito fundamental previsto na Constituição brasileira de 1988. Nesse sentido, antes de se adentrar à temática específica da pesquisa, será realizado um estudo, ainda que breve, acerca da liberdade religiosa no texto da Constituição da República Federativa do Brasil de 1988 (CRFB/88).

\section{A COMPREENSÃO DA LIBERDADE RELIGIOSA NO CONTEXTO DA CONSTITUIÇÃO DA REPÚBLICA FEDERATIVA DO BRASIL DE 1988}

\footnotetext{
8 Percebe-se que o constituinte, como também o legislador brasileiro, não conseguem harmonizar ou compreender, de maneira razoável, bases axiológicas do princípio da liberdade religiosa, tendo dificuldade em coadunar Estado laico, liberdade religiosa, igualdade e democracia.
}

\section{Revista de Direito Penal, Processo Penal e Constituição | e-ISSN: 2526-0200 | Maranhão |} v. 3 | n. 2 | p. 17 - 40 | Jul/Dez. 2017. 
Ao se estudar o princípio da liberdade religiosa no texto da Constituição de 1988, a primeira observação decorre do seu preâmbulo, que possui o seguinte enunciado:

\begin{abstract}
Nós, representantes do povo brasileiro, reunidos em Assembleia Nacional Constituinte para instituir um Estado Democrático, destinado a assegurar o exercício dos direitos sociais e individuais, a liberdade, a segurança, o bem-estar, o desenvolvimento, a igualdade e a justiça como valores supremos de uma sociedade fraterna, pluralista e sem preconceitos, fundada na harmonia social e comprometida, na ordem interna e internacional, com a solução pacífica das controvérsias, promulgamos, sob a proteção de Deus, a seguinte CONSTITUIÇÃO DA REPÚBLICA FEDERATIVA DO BRASIL. (BRASIL, 2017b).
\end{abstract}

O preâmbulo, como parte introdutória do texto constitucional, tem por finalidade apresentar as intenções, objetivos e bases político-filosóficas da Constituição, apresentando em seu corpo elementos caracterizadores fundamentais para o ordenamento jurídico brasileiro: a intenção de se assegurar o exercício de direitos sociais e individuais, liberdade, segurança, bem-estar, desenvolvimento, igualdade, justiça, como valores supremos de uma sociedade fraterna, servindo também como mecanismo de auxílio à interpretação constitucional, tendo em vista o fato de o mesmo apresentar características importantes da ordem jurídico-constitucional.

O inciso VI do artigo $5^{\circ}$ da CRFB/88 objetiva proteger as liberdades de consciência, de culto e de crença, considerando “inviolável a liberdade de consciência e de crença, sendo assegurado o livre exercício dos cultos religiosos e garantida, na forma da lei, a proteção aos locais de culto e as suas liturgias”. (BRASIL, 2017b).

Sob tal contexto, não podem subsistir atos que violem a liberdade religiosa, ainda que tais atos se amparem na vontade da maioria e, com isso, estar-se-á a justificar atos que envolvem um caráter contramajoritário, mas que são plenamente válidos em defesa dos direitos fundamentais.

Essa dificuldade contramajoritária ${ }^{9}$, segundo Luis Roberto Barroso, encontra justificativas de natureza normativa e filosófica. O fundamento normativo decorre:

\footnotetext{
${ }^{9}$ Barroso atribui essa expressão a Alexandre Bickel, The least dangerous branch, 1996, p. 16 e segs. In: (BARROSO, Luis Roberto. Judicialização, ativismo judicial e legitimidade democrática. Disponível em: <www.migalhas.com.br/mostra_noticia_articuladas.aspx?cod=77375>. Acesso em: 19 jun. 2017.
}

Revista de Direito Penal, Processo Penal e Constituição | e-ISSN: 2526-0200 | Maranhão | v. 3 | n. 2 | p. 17 - 40 | Jul/Dez. 2017. 
Do fato de que a Constituição brasileira atribui expressamente esse poder ao Judiciário e, especialmente ao Supremo Tribunal Federal. A maior parte dos Estados democráticos reserva uma parcela de poder político para ser exercida por agentes que não são recrutados pela via eleitoral, e cuja atuação é de natureza predominantemente técnica e imparcial. (BARROSO, 2017).

Já a justificativa filosófica repousaria na circunstância de que o respeito aos direitos fundamentais impõe a limitação do poder (fundamentos do constitucionalismo), de tal modo que o exercício do poder fundando na soberania popular expressada na vontade da maioria, que caracteriza o regime democrático, deve respeitar os direitos fundamentais, o que enseja a possibilidade de conflito entre vontade da maioria e a proteção aos direitos fundamentais, que deve ser conformado pela Constituição, de onde resultaria a missão do Judiciário de velar pelo respeito aos valores e direitos fundamentais, sem descurar da preservação do princípio majoritário. (BARROSO, 2017).

A observação de Barroso não pode ser olvidada quando insiste em que a democracia não se resume ao princípio majoritário e problematiza:

\footnotetext{
Se houver oito católicos e dois muçulmanos em uma sala, não poderá o primeiro grupo deliberar jogar o segundo pela janela, pelo simples fato de estar em maior número. Aí está o segundo papel da Constituição: proteger valores e direitos fundamentais, mesmo que contra a vontade circunstancial de quem tem mais votos. (BARROSO, 2017).
}

Esse é, aliás e a bem da verdade, o sentido da tolerância no Estado Democrático de Direito, vale dizer: o respeito e a efetividade dos direitos fundamentais das minorias em face da vontade da maioria.

\section{A PROTEÇÃO PENAL DA LIBERDAdE RELIGIOSA NO ORDENAMENTO JURÍDICO BRASILEIRO}

O Direito Penal é o ramo do ordenamento jurídico incumbido de definir as condutas proibidas que afetam os bens mais importantes da pessoa humana e da sociedade, como a vida, o patrimônio, a moralidade na administração pública, a incolumidade pública, a honra, o sentimento religioso.

Revista de Direito Penal, Processo Penal e Constituição | e-ISSN: 2526-0200 | Maranhão | v. 3 | n. 2 | p. 17 - 40 | Jul/Dez. 2017. 
No ordenamento jurídico brasileiro, o tratamento penal da liberdade religiosa está previsto diretamente no Título V (Crimes contra o sentimento religioso e contra o respeito aos mortos) do Decreto-Lei 2848, de 7 de dezembro de 1940 - Código Penal brasileiro (reformado em 1984), que define os crimes contra o sentimento religioso e contra o respeito aos mortos, dedicando aos mesmos dois capítulos: Capítulo I - Dos crimes contra o sentimento religioso; e Capítulo II - Dos crimes contra o respeito aos mortos. Para tanto, dedicou ao tema cinco tipos penais, dos artigos 208 ao 212, todos de ação penal pública incondicionada. ${ }^{10}$

Além do referido Título V, o parágrafo terceiro do artigo 140 prevê o crime de injúria racial ou preconceituosa, que pode se relacionar também à forma religiosa, conforme previsto à frente. O artigo 140 está inserido no Título I da Parte Especial do Código Penal (CP), sob o nomen juris (Crimes contra a Pessoa). Além do CP, a liberdade religiosa também é tutelada pela Lei n. ${ }^{\circ} 7.716$ de 1989.

Fato é que, o tratamento da proteção penal da liberdade religiosa no direito brasileiro é breve e ineficiente, seja no aspecto da criminalização primária, quanto na criminalização secundária. Nesse sentido, é de se observar que, na realidade, há poucas condenações ou processos relacionados a aspectos penais da liberdade religiosa, como também o espaço dado ao tema nas faculdades de Direito é insignificante.

Ademais, não é incomum a proteção deficiente da liberdade religiosa na prática judicial. Nesse sentido, tem-se como exemplo uma decisão do juiz federal da $17^{\text {a }}$ Vara Federal do Rio de Janeiro ${ }^{11}$ que, inicialmente, ao apreciar pedido do Ministério Público Federal de retirar do youtube vídeos ofensivos às religiões da umbanda e do candomblé, indeferiu o pedido, fundamentando não conterem, a umbanda e o candomblé, os traços necessários de

\footnotetext{
${ }^{10}$ Interessante observar que, os artigos 209 a 212 do Código Penal, obliquamente, podem se relacionar com a liberdade religiosa, na medida em que é possível considerar o ritual do enterro e o respeito ao cadáver e às suas cinzas como parte da liberdade de crença. Porém, não se trata diretamente de proteção à liberdade religiosa, motivo pelo qual esses dispositivos não foram expostos no catálogo.

11 BRASIL. Tribunal Regional Federal (2 Região). Ação Civil Pública. Processo n. ${ }^{\circ}$ 000474733.2014.4.02.5101 (2014.51.01.004747-2), movida pelo Ministério Público Federal contra GOOGLE BRASIL INTERNET LTDA. Disponível em: <www.conjur.com.br/...juiz-recua-manifestacoes-religioes-africanasmantem-decisao>. Acesso em: 11 abr. 2017.
}

Revista de Direito Penal, Processo Penal e Constituição | e-ISSN: 2526-0200 | Maranhão | v. 3 | n. 2 | p. 17 - 40 | Jul/Dez. 2017. 
uma religião. Posteriormente, o magistrado modificou seu entendimento, após manifestações de grupos religiosos na imprensa.

Por outro lado, há casos em que o Judiciário protegeu a liberdade religiosa nos termos da tutela constitucional. Nesse sentido, a pesquisa de Carlos Tomaz e Henrique Lelis revela:

Na cidade de Camaçari no Estado da Bahia, a defensoria pública conseguiu uma decisão liminar em ação indenizatória por danos morais, movida contra os integrantes da igreja evangélica denominada “Casa de oração Ministério de Cristo”, proibindo seus integrantes de realizarem qualquer ato religioso contrário aos praticantes do candomblé, em especial aos frequentadores do Terreiro Oyá Denã. O caso chegou ao judiciário após estes evangélicos realizarem um ato religioso em frente a sede da igreja africana. Por uma noite inteira, os reus fizeram um intenso ato de "evangelização" e "exorcismo” dos frequentadores do terreiro. Naquele dia, a Sra Mildreles Dias Ferreira de 90 anos, “mãe de santa” deste terreiro, não suportou o estresse, sofreu um infarto e faleceu. (Defensoria Pública do Estado da Bahia, 2015). No ano de 2005, a quarta vara da justiça federal da Bahia, determinou por meio de liminar a suspensão da venda do livro "Orixás, Caboclos e Guias: Deuses ou Demônios?”, escrito pelo Bispo Edir Macedo, um dos fundadores da igreja Universal do Reino de Deus. A ação civil pública, movida pelo Ministério Público Federal, teve como base a acusação de que tal publicação fere a dignidade humana daqueles que são adeptos das religiões africanas, sendo um instrumento de proliferação de discurso de ódio e de intolerância. (Folha de São Paulo, 2005). (TOMAZ; LELIS, 2017).

Tomaz e Lelis ainda evidenciam alguns acontecimentos que revelam a intolerância que a questão envolve:

Em Belo Horizonte, o Pastor Lucinho em uma de suas pregações, ensinou os jovens frequentadores de sua igreja como realizar o proselitismo e evangelização dos praticantes de outras religiões, em especial os de matriz africana, incluindo a “infiltração” em atos religiosos realizados por estas religiões. Na cidade de Manaus, Amazonas, alunos evangélicos se recusaram a participar de uma feira cultural sobre cultura negra, argumentando princípios religiosos. Alegavam que o tema fazia apologia ao satanismo e ao homossexualismo. Orientados por pastores evangélicos, os alunos diziam que a questão deve ser encarada pelo lado religioso. "A Bíblia Sagrada nos ensina que não devemos adorar outros deuses e quando realizamos um trabalho desses estamos compactuando com a ideia de que outros deuses existem e isso fere as nossas crenças no Deus único", alegou um dos alunos. (Globo, 2012). No início do ano de 2015, a igreja Universal do Reino de Deus ganhou a atenção da mídia nacional ao lançar e divulgar os "Gladiadores do Altar”, um grupo de jovens treinados nos moldes militares com a finalidade de pregar o evangelho e realizar atos de persuasão, com a finalidade de angariar novos adeptos para a igreja. (UOL notícias, 2015). (TOMAZ; LELIS, 2017).

Revista de Direito Penal, Processo Penal e Constituição | e-ISSN: 2526-0200 | Maranhão | v. 3 | n. 2 | p. 17 - 40 | Jul/Dez. 2017. 
Ora, em alguns dos casos relatados foram descortinados aspectos cíveis e deixadas de lado as possíveis incursões na esfera penal. Isso justifica, sem dúvida, uma reflexão da matéria no âmbito da tutela penal.

\subsection{Crimes contra o sentimento religioso}

Nos tempos antigos, a religião estava intimamente ligada ao conceito de Estado, de modo que, ao se ferir a religião, consequentemente, feria-se o Estado. ${ }^{12}$ " $\mathrm{O}$ dever religioso era um dever político. O crime contra a religião era crime contra o Estado. A profanação de um templo ou impedimento de um ato religioso, quando intencionais, constituíam atentados contra a ordem estatal”. (HUNGRIA; LACERDA; FRAGOSO, 1981, p. 49).

O capítulo I do Título V do Código Penal de 1940 arrola os crimes contra o sentimento religioso, com apenas um tipo penal, o do artigo 208, que prevê em seu interior 3 condutas proibidas.

Neste sentido, o tipo penal do referido artigo 208 determina a conduta de "escarnecer de alguém publicamente, por motivo de crença ou função religiosa; impedir ou perturbar cerimônia ou prática de culto religioso; vilipendiar publicamente ato ou objeto de culto religioso". Em realidade, o tipo penal subdivide-se em três ilícitos penais distintos, cuja finalidade é tutelar o preceito constitucional estampado no inciso VI do artigo $5^{\circ}$ da Constituição da República Federativa do Brasil de 1988 - CRFB/88, que determina ser “inviolável a liberdade de consciência e de crença, sendo assegurado o livre exercício dos cultos religiosos e garantida, na forma da lei, a proteção aos locais de culto e as suas liturgias”. Deste modo, todo cidadão tem o direito de manifestar sua fé por intermédio da religião que melhor se adapte às suas convicções, motivo pelo qual o tipo penal tutela tanto o sentimento religioso, quanto a liberdade de culto.

Todas as três condutas são comuns, no que se refere ao sujeito ativo, o que significa que não exigem característica especial por parte daquele que praticá-las. Por sua vez, no que

\footnotetext{
${ }^{12}$ Na própria sociedade romana, não havia diferença jurídica entre as res sacrae e as res publicae, ou seja, entre a coisa sacra e a coisa pública.
}

Revista de Direito Penal, Processo Penal e Constituição | e-ISSN: 2526-0200 | Maranhão | v. 3 | n. 2 | p. 17 - 40 | Jul/Dez. 2017. 
se refere aos sujeitos passivos, cabem observações próprias: na primeira conduta, "escarnecer de alguém publicamente, por motivo de crença ou função religiosa," tem-se como vítima aqueles que sofrem o escárnio público, por motivo de crença ou função religiosa, enquanto que, nas duas últimas condutas "impedir ou perturbar cerimônia ou prática de culto religioso; vilipendiar publicamente ato ou objeto de culto religioso", trata-se de crime vago, atingindo número indeterminado de pessoas.

Deste modo, é a própria sociedade, como um todo, ofendida quando ocorre a prática da referida conduta penal.

\subsubsection{Escarnecer de alguém publicamente, por motivo de crença ou função religiosa}

Atualmente o Brasil ainda é um país de expressiva maioria católica, passando, todavia, por importantes transformações no seu perfil demográfico religioso. Dados do censo nacional de 2010 apontam, ainda ser o Brasil a maior nação católica do mundo, apesar do aumento do número de evangélicos. Neste sentido, entre os anos de 1960 a 2010, “o percentual da população que se declara católica diminuiu de $93,1 \%$ para 64,6\%. No mesmo período, o percentual de evangélicos cresceu de 4,0\% para 22,2\%”. (PEREIRA, 2014).

Em relação às religiões minoritárias, as de matriz afro-brasileiras, como é o caso do candomblé africano e da umbanda brasileira, o percentual é de 0,3\% da população brasileira. Porém, em que pese o número consideravelmente pequeno de praticantes, essas religiões são importantes pela influência que exercem na liturgia e práticas de outras religiões por intermédio do sincretismo, que tem como origem o processo de catequização de negros africanos escravizados, o que ocasionou a incorporação de diversos elementos das suas tradições religiosas ao cristianismo hegemônico desde o período colonial, consubstanciando um emaranhado de práticas, liturgias, símbolos e crenças. Outro fato importante é o "histórico de estigma e intolerância a elas dirigidos, com reflexos importantes na esfera pública e nas demandas por liberdade e laicidade”. (PEREIRA, 2014).

Essa situação é potencialmente geradora do escárnio público por motivo de crença ou função religiosa.

Revista de Direito Penal, Processo Penal e Constituição | e-ISSN: 2526-0200 | Maranhão | v. 3 | n. 2 | p. 17 - 40 | Jul/Dez. 2017. 
Analiticamente, o tipo objetivo do ilícito é o ultraje público por motivo religioso, que consiste em o sujeito ativo escarnecer de alguém publicamente, por motivo de crença ou função religiosa. Por escarnecer entende-se ridicularizar, insultar, zombar ou humilhar, que deve se dirigir a determinada pessoa em razão de sua crença ou função religiosa. Verifica-se também que o termo publicamente é elemento fundamental para a caracterização do injusto, ou seja, não basta que o escárnio tenha motivação religiosa, necessitando ainda que seja praticado na presença de várias pessoas ou por intermédio de instrumentos que possam propagar tal ultraje, como jornal, televisão, rádio, cartaz, outdoor, alcançando pessoas indeterminadas.

É necessário ainda que o ultraje ocorra em decorrência de crença ou função religiosa. Neste sentido, de acordo com Victor Eduardo Rios Gonçalves:

O agente zomba, ridiculariza, ofende a vítima, quer em razão da fé que professa, quer em decorrência de sua função religiosa (padre, rabino, freira, coroinha, pastor). É necessário que o escárnio ocorra em público, ainda que a vítima não esteja presente. Se o fato não ocorrer em público, poderá ser tipificado o crime de injúria. (GONÇALVES, 2013, p. 525).

A doutrina destaca exigir o tipo penal que a ofensa seja contra alguém, ou seja, contra pessoa ou pessoas determinadas, em razão de sua religiosa ou função religiosa.

Em relação ao tipo subjetivo, inexiste a modalidade culposa, sendo o crime punível apenas na modalidade dolosa, que no caso se caracteriza pela vontade livre e consciente do agente em praticar qualquer das condutas previstas na norma penal incriminadora. É relevante destacar ser imprescindível o especial motivo de agir, consistente no sentido de que o agente atue em razão de crença ou função religiosa ou com o objetivo de ofender o sentimento religioso do sujeito passivo, pois do contrário, configurará apenas o crime de difamação ou injúria, previstos nos artigos 139 ou 140 do Código Penal.

Em relação ao seu momento consumativo, trata-se de crime de mera conduta, que se consuma no momento em que o agente insultar de alguém publicamente, por motivo de crença ou função religiosa. Sendo admissível a tentativa quando o escárnio for praticado por 
escrito, e a ação for interrompida por circunstâncias alheias à vontade do agente antes da consumação.

\subsubsection{Impedir ou perturbar cerimônia ou prática de culto religioso}

A segunda conduta consiste em impedir ou perturbar cerimônia ou prática de culto religioso. Neste caso, a norma incriminadora responsabiliza o agente que não permitir o início, obstar ou suspender o andamento regular da cerimônia ou culto, seja, perturbando, tumultuando, alterando ou atrapalhando o seu curso regular. Para a caracterização do crime é necessário que a conduta do agente seja de considerável monta, ou seja, capaz de romper com a continuidade do evento.

Por cerimônia entende-se a manifestação exterior do culto religioso, como a missa, culto, batismo, casamento, procissão, não necessitando ser realizada dentro de uma igreja ou templo, podendo o ato ocorrer fora dessas locais. Por sua vez, prática de culto religioso é uma atividade menos solene, todavia relacionada ao culto, como exemplo de oração coletiva na igreja, mesquita ou sinagoga.

Quanto ao momento consumativo, a consumação ocorre quando o agente efetivamente interromper ou atrapalhar o culto ou cerimônia religiosa, tratando-se deste modo de crime material, ou seja, crime que possui resultado naturalístico e a ocorrência do mesmo é imprescindível para sua caracterização.

\subsubsection{Vilipendiar publicamente ato ou objeto de culto religioso}

Um caso concreto relacionado ao referido tipo penal ocorreu no ano dia 12 de outubro de 1995, dia de Nossa Senhora de Aparecida, Padroeira do Brasil, ocasião em que um bispo da Igreja Universal do Reino de Deus (de religião protestante), Sérgio Von Helder, chutou publicamente, durante um programa televisivo matutino, a imagem de Nossa Senhora. O episódio que ficou conhecido como "um chute na santa” ocorreu enquanto o bispo protestava contra o feriado nacional de 12 de outubro. O acontecimento provocou considerável repercussão em considerável parcela da sociedade brasileira.

Revista de Direito Penal, Processo Penal e Constituição | e-ISSN: 2526-0200 | Maranhão | v. 3 | n. 2 | p. 17 - 40 | Jul/Dez. 2017. 
Após o incidente iniciou-se um conflito midiático entre a emissora de televisão Rede Record, de propriedade da Igreja Universal do Reino de Deus, e a Rede Globo, que considerou a prática uma ofensa ao povo brasileiro.

Fato é que a questão despertou a atenção para questões fundamentais relacionadas à democracia: i) a intolerância; ii) o discurso de ódio; e iii) a liberdade religiosa como direito fundamental.

O Poder Judiciário brasileiro condenou o bispo a dois anos e dois meses de privação de liberdade no dia 30 de abril de 1997, sendo o caso caracterizado como inédito no ordenamento jurídico brasileiro. Para que a condenação ocorresse, é necessário questionar a influência da midiatização penal, que, certamente foi fundamental para que a situação não se tornasse mais um fato esquecido e impune.

\subsection{A injúria racial (religiosa)}

O parágrafo terceiro do artigo 140 do Código Penal trata a injúria racial ou preconceituosa, tendo o dispositivo a seguinte redação: “se a injúria consiste na utilização de elementos referentes a raça, cor, etnia, religião, origem ou a condição de pessoa idosa ou portadora de deficiência”. Trata-se de forma qualificada do crime de injúria, tendo sido o parágrafo terceiro inserido no Código Penal no ano de 1997, ou seja, cinquenta e sete anos após sua publicação.

Como todos os crimes contra a honra previstos no Código Penal brasileiro (calúnia, injúria e difamação), a injúria racial (religiosa) pressupõe que a ofensa seja endereçada a pessoa determinada, ou, ao menos, a um grupo determinado de indivíduos. “Assim, quando o agente se dirige a uma outra pessoa e a ofende fazendo referência à sua cor ou religião, configura-se a injúria qualificada”. (GONÇALVES, 2013, p. 263).

O crime se consuma no momento em que a injúria proferida chega ao conhecimento da vítima. Deste modo, caso a ofensa aconteça na sua presença, a consumação é imediata. Do contrário, não estando presente a vítima, o aperfeiçoamento somente se dará no momento em que chegar ao seu conhecimento.

Revista de Direito Penal, Processo Penal e Constituição | e-ISSN: 2526-0200 | Maranhão | v. 3 | n. 2 | p. 17 - 40 | Jul/Dez. 2017. 
Assim, haverá a consumação da injúria quando, por exemplo, não se permitir a uma pessoa ficar sócia de um clube em decorrência de sua fé religiosa, ou proibir uma pessoa de se alimentar em um restaurante por causa de sua religião professada.

\subsection{O preconceito ou discriminação por motivação religiosa}

A Lei n. ${ }^{\circ}$ 7.716, de 5 de janeiro de 1989, que define os crimes resultantes de preconceito de raça ou de cor, define a punição para os crimes resultantes de discriminação ou preconceito de raça, cor, etnia, religião ou procedência nacional.

Se comparada aos dispositivos supracitados, é possível perceber nessa lei um raio de proteção legal muito superior, prevendo a criminalização desde o preconceito praticado na Administração Pública direta ou indireta e Forças Armadas (arts. $3^{\circ}$ e 13), passando pelas empresas privadas (art. $4^{\circ}$ ), estabelecimentos de ensino público ou privado (art. $6^{\circ}$ ), hoteis, bares, restaurantes (arts. $7^{\circ}$ e $8^{\circ}$ ), meios de transporte (art. 12), até a prática por intermédio da rede mundial de computadores (inciso II, parágrafo terceiro, art. 20).

Além da maior amplitude do tipo penal, no que se refere às situações protegidas, a lei considera os crimes previstos como sendo de médio ou de elevado potencial ofensivo.

Apresentados um estudo dogmático acerca dos dispositivos penais relacionados à proteção da liberdade religiosa, passa-se na próxima subseção à analise da atual situação da intolerância e da discriminação religiosa no Brasil.

\subsection{A atual situação da intolerância e da discriminação religiosa no Brasil}

Em que pese a existência de legislação objetivando a proteção da liberdade religiosa no Brasil, a realidade mostra um cruel quadro de ofensas aos postulados dessa liberdade. Nesse sentido, os dados de realidade apresentam situações graves, como violência contra praticantes do candomblé, principalmente nos Estados do Rio de Janeiro e Bahia. ${ }^{13}$

\footnotetext{
${ }^{13}$ Como exemplo, tem-se a violência contra Kaylane Santos, então com 11 anos de idade, ocorrida no dia 14 de junho de 2015, amplamente noticiada na imprensa. À época, a menor foi apedrejada por evangélicos após sair de uma celebração do candomblé, acompanhada por amigos e familiares, na Vila da Penha, no Rio de Janeiro. Os
}

Revista de Direito Penal, Processo Penal e Constituição | e-ISSN: 2526-0200 | Maranhão | v. 3 | n. 2 | p. 17 - 40 | Jul/Dez. 2017. 
Os dados de realidade apresentam, ainda, vandalismos em templos religiosos. ${ }^{14}$ Porém, a violência não se concentra apensa em locais de culto, atingindo, ainda, monumentos públicos com conotação religiosa. ${ }^{15}$

Interessante observar a discrepância existente entre i) os dados noticiados pela imprensa; ii) os casos levados às ouvidorias ${ }^{16}$ de órgãos de proteção; iii) os casos que chegam ao Poder Judiciário.

Em relação aos casos noticiados pela imprensa, de acordo com o Relatório sobre Intolerância e Violência Religiosa no Brasil (RIVIR), da Secretaria Especial de Direitos Humanos do Ministério das Mulheres, da Igualdade Racial, da Juventude e dos Direitos Humanos, de 2016, após levantamento realizado nos principais jornais escritos e eletrônicos dos 27 Estados brasileiros e do Distrito Federal, houve 94 noticiados em 2015, contra 48 em 2014. No ano de 2013 foram noticiados 31 casos, em 2012, 35 casos e 24 casos noticiados no ano de 2011.

Em relação à religião das vítimas (referentes aos casos noticiados pela imprensa), a maioria absoluta é constituída por adeptos das religiões de matriz africana (53\%), seguida por católicos (9\%) e evangélicos (8\%). (RIVIR, 2016).

Dentre os anos de 2011 a 2015, apenas $110 \operatorname{casos}^{17}$ relativos à intolerância religiosa tornaram-se processos judiciais, conforme mostra o RIVIR. Em relação à religião das vítimas,

agressores, evangélicos e com bíblias em punho, a chamavam de diabo, dizendo que todos iriam queimar no inferno.

${ }^{14}$ Interessante observar que, o tema da intolerância religiosa foi tema do Exame Nacional do Ensino Médio (Enem), na sua edição de novembro de 2016. Porém, um dia antes, ocorreu a depredação e o incêndio de uma casa de candomblé na Estrada Rio-Bahia, em Teresópolis, Estado do Rio de Janeiro. Em março de 2016, um auxiliar de limpeza foi esfaqueado três vezes, por acender velas na rua, pelo vizinho, que é pastor evangélico. $\mathrm{O}$ fato ocorreu em Praia Grande-SP.

${ }^{15}$ Nesse sentido, no dia 4 de maio de 2016, o busto de Mãe Gilda, localizado no Parque do Abaeté, em Itapuã, Salvador, foi alvo de vândalos, tendo a placa de informações apagada. Em Brasília, as 16 estátuas situadas no Parque dos Orixás, Lago Sul, são frequentemente atacadas por intolerantes religiosos, além dos vândalos comuns.

${ }^{16}$ De acordo com o Relatório sobre Intolerância e Violência Religiosa no Brasil (RIVIR), o número de denúncias recebidas por Ouvidorias no Brasil, no período entre 2011-2015 é o seguinte: Secretaria de Justiça, Direitos Humanos e Cidadania Sejusc - AM: 20; Secretaria de Direitos Humanos: 756; Secretaria de Estado da Segurança Pública e Defesa Social do Estado do ES: 19; Ouvidoria da Secretaria de Justiça e Direitos Humanos de PE: 1; Ouvidoria Geral do Distrito Federal: 9; Ouvidoria do Ministério da Justiça: 5; Ouvidoria Geral da União: 10; Ouvidoria da Câmara Municipal de Salvador: 18; Ouvidoria do Ministério Público do Estado do Rio de Janeiro: 83; Ouvidoria do Ministério Público do Estado de São Paulo: 110, totalizando 1031 denúncias no período.

\section{Revista de Direito Penal, Processo Penal e Constituição | e-ISSN: 2526-0200 | Maranhão |}

$$
\text { v. } 3 \text { | n. } 2 \text { | p. } 17 \text { - } 40 \text { | Jul/Dez. } 2017 .
$$


nos processos judiciais, tem-se os seguintes números: adventistas (45\%), evangélicos (11\%), religiões de matriz africana (7\%), católicos (6\%). (RIVIR, 2016, p. 79).

De acordo com relatório produzido pela Fundação Pew em que é apresentado o “Índice de Hostilidades Sociais por motivações religiosas”, no ano de 2015 o Brasil passou da posição de um dos 25 países mais populosos com menor taxa, estando entre aqueles que eram considerados com muito baixa hostilidade social $(0,0$ a 1,0$)$ por motivos religiosos em 2007, para um dos países com alta taxa em $2013\left(3,5\right.$ a 7,0). ${ }^{18}$

Em síntese, é grave a situação de desrespeito à liberdade de religião no Brasil. Atualmente observa-se um aumento da intolerância religiosa no cotidiano social, o que mostra que a sociedade está na contramão do respeito ao outro e à sua individualidade.

\section{CONCLUSÃO}

O Brasil, de acordo com dados do Instituto Brasileiro de Geografia e Estatística, continua sendo o maior país católico do mundo, apesar da diminuição expressiva do percentual da população que se declara católica e, de outro lado, do aumento, também significativo, do percentual de evangélicos.

Soma-se a isso a expressiva quantidade da população que se declara como adeptos do candomblé, umbanda e demais religiões de matriz afro, como também ao islamismo, tornando o Brasil um país religiosamente miscigenado. Apesar de pequeno o percentual, essas religiões são importantes historicamente, em decorrência da influência que exercem na liturgia e práticas de outras religiões por intermédio do sincretismo, originado pelo processo de catequização de negros africanos escravizados.

Estudando a história social e jurídica da liberdade religiosa no Brasil, observou-se a presença de duas fases: a fase confessional e a fase laica. A fase confessional se elasteceu até o ano de 1891, percorrendo todo o período colonial e imperial brasileiro. Por sua vez, a fase

\footnotetext{
17 Tem-se os seguintes números por ano: ano de 2011: 13; ano de 2012: 12; ano de 2013: 23; ano de 2014 : 31 e ano de 2015: 31.

18 O índice é construído a partir da identificação sistemática da ocorrência de episódios de intolerância e violência religiosa, sendo avaliada também a intensidade com que ocorrem.
}

Revista de Direito Penal, Processo Penal e Constituição | e-ISSN: 2526-0200 | Maranhão | v. 3 | n. 2 | p. 17 - 40 | Jul/Dez. 2017. 
laica teve início com a Constituição de 1891, permanecendo até os dias atuais, com a atual Constituição da República Federativa do Brasil de 1988.

Durante o período colonial (1822-1889) o regime do padroado proporcionou a possibilidade de os sacerdotes serem indicados e remunerados pelo Estado, assumindo condição semelhante à de servidores públicos. Ademais, a Constituição de 1824 previa a necessidade de assentimento do monarca para que as bulas e encíclicas papais pudessem ser validadas pelo Estado brasileiro (era a fase confessional do Estado).

Por sua vez, a Constituição republicana de 1891 inaugurou o modelo de separação entre religião e Estado, que foi seguido por todas as constituições posteriores. Neste sentido, seguiram o modelo as constituições de 1934, 1937, 1946 e 1967, todas prevendo expressamente o modelo laico de Estado.

Em que pese a previsão do Estado laico no texto constitucional da Constituição de 1988, questões jurídicas relacionadas ao princípio da liberdade religiosa ainda requerem um cuidado especial das instituições brasileiras, principalmente levando-se em consideração a tradição histórica da presença da religião católica, que possui muita influência no Estado brasileiro, além do crescimento da participação dos evangélicos no poder político.

A colonização brasileira teve como bases a fé, a cruz e a espada, com a religião assumindo importante papel na construção da identidade nacional, haja vista os feriados nacionais, os símbolos nacionais, os nomes de ruas com nomes de santos católicos. Porém, o princípio da laicidade estatal não permite que a religião interfira em decisões políticas estatais.

A intolerância religiosa tem propiciado condutas que tem ensejado ampla discussão social e reflexos na jurisdição cível, não têm, em regra, sido objeto de exame na esfera penal não obstante a existência de um quadro normativo para tanto.

Diante de dificuldade contramajoritária impõe sempre a observância do consenso estabelecido na Constituição que compreende a liberdade religiosa como direito fundamental, obviamente e inclusive da minoria, não se pode olvidar.

O Estado Democrático de Direito demanda uma proteção penal eficaz da liberdade religiosa, que é um bem fundamental do indivíduo. Neste sentido, entende-se que existe, no

Revista de Direito Penal, Processo Penal e Constituição | e-ISSN: 2526-0200 | Maranhão | v. 3 | n. 2 | p. 17 - 40 | Jul/Dez. 2017. 
caso brasileiro, uma proteção ineficaz da liberdade religiosa, haja vista as penas em abstrato que estão previstas num percentual que não coaduna com a seriedade e o respeito que a liberdade religiosa demanda, como também a timidez das decisões judiciais, que desconsidera a relevância da proteção da religião como bem jurídico-penal.

Nesse sentido, não pode ser esquecida a cifra negra da criminalidade relativa aos crimes que envolvem a liberdade de religião. A pesquisa apresenta a disparidade entre os números referentes às notícias relativas às ofensas praticadas contra a liberdade religiosa, as denúncias apresentadas nas ouvidorias e os casos que efetivamente são levados ao Poder Judiciário, o que mostra a proteção deficiente da liberdade religiosa no ordenamento jurídico brasileiro.

\section{REFERÊNCIAS}

ABBAGNANO, Nicola. Dicionário de filosofia. 5. ed. São Paulo: Martins Fontes, 2007.

ADRAGÃO, Paulo Pulido. A liberdade religiosa e o estado. Coimbra: Almedina, 2002.

ALVES, Otton Moreno de Medeiros. Liberdade religiosa institucional: direitos humanos, direito privado e espaço jurídico multicultural. Fortaleza: Fundação Konrad Adenauer, 2008.

ARRIADA LOREA, Roberto (Org.) Em defesa das liberdades laicas. Porto Alegre: Livraria do Advogado, 2008.

BARROSO, Luis Roberto. Judicialização, ativismo judicial e legitimidade democrática. Disponível em: <www.migalhas.com.br/mostra_noticia_articuladas.aspx?cod=77375>. Acesso em: 19 jun. 2017.

BITTENCOURT, Circe (Org.) Dicionário de datas da história do Brasil. São Paulo: Contexto, 2007.

BLANCARTE PIMENTEL, Roberto Javier. Libertad religiosa y no discriminación. Cidade do México: Consejo Nacional para Prevenir la Discriminación, 2008.

BOTO, Carlota. 28 de junho de 1759: reforma pombalina. In: BITTENCOURT, Circe (Org.)

Dicionário de datas da história do Brasil. São Paulo: Contexto, 2007, pp. 145-148. 
BRASIL. Constituição (1824) Constituição política do império do Brasil. Disponível em <http://www.planalto.gov.br/Ccivil_03/Constituicao/Constitui\%C3\%A7ao24.htm>. Acesso em 3 jul. 2017 .

BRASIL. Constituição (1988) Constituição da república federativa do Brasil. Disponível em: <http://www.planalto.gov.br/ccivil_03/constituicao/constituicao.htm>. Acesso em: 30 maio 2017b.

BRASIL. Decreto n. ${ }^{0}$ 119-A, de 7 de janeiro de 1890. Disponível em <http://www.planalto.gov.br/ccivil_03/decreto/1851-1899/d119-a.htm>. Acesso em: 8 ago. 2017c.

BRASIL. Tribunal Regional Federal (2 Região). Ação Civil Pública. Processo n. ${ }^{\circ} 0004747-$ 33.2014.4.02.5101 (2014.51.01.004747-2), movida pelo Ministério Público Federal contra GOOGLE BRASIL INTERNET LTDA. Disponível em: <www.conjur.com.br/...juiz-recuamanifestacoes-religioes-africanas-mantem-decisao>. Acesso em: 11 abr. 2017.

BUENO, José Antônio Pimenta. Direito público brasileiro e análise da constituição do império. Brasília: Senado Federal, 1978.

CANOTILHO, José Joaquim Gomes. Direito constitucional. Coimbra: Almedina, 1993.

CHEHOUD, Heloísa Sanches Querino. A liberdade religiosa nos estados modernos. São Paulo: Almedina, 2012.

CHIASSONI, Pierluigi. Laicidad y libertad religiosa. Cidade do México: UNAM, 2013. (Coleção “Jorge Carpizo” - Para entender y pensar la laicidad).

DIMOULIS, Dimitri; MARTINS, Leonardo. Teoria geral dos direitos fundamentais. São Paulo: Revista dos Tribunais, 2007.

DORNAS FILHO, João. O padroado e a igreja brasileira. São Paulo: Companhia Editora Nacional, 1938.

GOUVEIA, Jorge Bacelar. Direito, religião e sociedade no estado constitucional. Lisboa: IDILP, 2012.

HUNGRIA, Nélson; LACERDA, Romão Côrtes; FRAGOSO, Heleno Cláudio. Comentários ao código penal. 5. ed. Rio de Janeiro: Forense, 1981, vol. VIII.

HORTA, Luiz Paulo. (Org.) Sagrado e profano: XI retratos de um Brasil fim de século. Rio de Janeiro: Agir, 1994. 
HUACO, Marco. A laicidade como princípio constitucional no estado de direito. In:

ARRIADA LOREA, Roberto (Org.) Em defesa das liberdades laicas. Porto Alegre: Livraria do Advogado, 2008, pp. 33-80.

MACHADO, Jónatas Eduardo Mendes. Liberdade religiosa numa comunidade constitucional inclusiva: dos direitos da verdade aos direitos dos cidadãos. Coimbra: Coimbra, 1996.

MARTINS FILHO, Ives Gandra da Silva; NOBRE, Milton Augusto de Brito (Org.) O estado laico e a liberdade religiosa. São Paulo: LTr, 2011.

MIRABETE, Julio Fabbrini. Código penal comentado. 7 ed. São Paulo: Atlas, 2011.

MIRANDA, Jorge. Manual de direito constitucional. Tomo IV, direitos fundamentais. 4 ed. Coimbra: Coimbra, 2008.

MORAIS, Márcio Eduardo Pedrosa. Liberdade religiosa: o ensino religioso na Assembleia Nacional Constituinte de 1987-88. Curitiba: Juruá, 2015.

MORAIS, Márcio Eduardo Pedrosa. Religião e direitos fundamentais: o princípio da liberdade religiosa no estado constitucional democrático brasileiro. Revista Brasileira de Direito Constitucional, São Paulo, n. 18, jul.dez. 2011.

OLIVEIRA, Marcos Marques. As origens da educação no Brasil: da hegemonia católica às primeiras tentativas de organização do ensino. Revista Ensaio, Rio de Janeiro, v. 12, n. 45, pp. 945-958, out./dez. 2004.

OLIVEIRA, Patrícia Elias Cozzolino de. A proteção constitucional e internacional do direito à liberdade de religião. São Paulo: Verbatim, 2010.

PEREIRA, Jane Reis Gonçalves. A aplicação de regras religiosas de acordo com a lei do Estado: um panorama do caso brasileiro. Revista da AGU, v. 41, pp. 9-42, 2014.

PORRAS RAMÍREZ, José Maria (Coord). Derecho de la libertad religiosa. 4. ed. Madri: Tecnos, 2016.

RELATÓRIO sobre intolerância e violência religiosa no Brasil (2011- 2015): resultados preliminares/Ministério das Mulheres, da Igualdade Racial, da Juventude e dos Direitos Humanos; Alexandre Brasil Fonseca, Clara Jane Adad (Orgs.). - Brasília: Secretaria Especial de Direitos Humanos, SDH/PR, 2016.

RIOS, José Arthur. Sentimento religioso no Brasil. In: HORTA, Luiz Paulo. (Org.) Sagrado e profano: XI retratos de um Brasil fim de século. Rio de Janeiro: Agir, 1994, pp. 21-46. 
SCAMPINI, José. A liberdade religiosa nas constituições brasileiras. Petrópolis: Vozes, 1978.

SILVA NETO, Manoel Jorge e. Proteção constitucional da liberdade religiosa. Rio de Janeiro: Lumen Juris, 2008.

SILVA, José Afonso da. Curso de direito constitucional positivo. 21. ed. São Paulo: Revista dos Tribunais, 2002.

TOMAZ, Carlos Alberto Simões de; LELIS, Henrique Rodrigues Lelis. O

Neopentacostalismo versus religiões de matriz Africana: uma análise sobre a restrição ao direito à liberdade religiosa. In: TOMAZ, Carlos Alberto Simões de; LEMOS JUNIOR, Eloy Pereira; MARTINS, Rui Decio (Org.). Direitos e Garantias Fundamentais I. CONPEDI Curitiba, 2016. Disponível em:

<https://www.conpedi.org.br/publicacoes/02q8agmu/z23nop3l/9r137y1vFr010Lcu.pdf>. Acesso em: 7 jun. 2017.

VAINFAS, Ronaldo; SOUZA, Juliana Beatriz de. Brasil de todos os santos. 2. ed. Rio de Janeiro: Jorge Zahar, 2002.

VILLA, Marco Antonio. A história das constituições brasileiras. São Paulo: Leya, 2011.

WEINGARTNER NETO, Jayme. Liberdade religiosa na constituição: fundamentalismo, pluralismo, crenças, cultos. Porto Alegre: Livraria do Advogado, 2007.

ZYLBERSZTAJN, Joana. O princípio da laicidade na constituição federal de 1988. 2012. 226 f. Tese (Doutorado) - Universidade de São Paulo, Programa de Pós-Graduação em Direito. 